Research Article

\title{
Bioactivities, chemical composition and nutritional value of Cynara cardunculus L. seeds
}

\author{
Spyridon Petropoulos ${ }^{\mathrm{a}, *}$, Ângela Fernandes ${ }^{\mathrm{b}}$, Carla Pereira ${ }^{\mathrm{b}}$, Nikos Tzortzakis ${ }^{\mathrm{c}}$, Josiana Vaz ${ }^{\mathrm{b}}$, \\ Marina Soković ${ }^{\mathrm{d}}$, Lillian Barros ${ }^{\mathrm{b}}$, Isabel C.F.R. Ferreira ${ }^{\mathrm{b}, *}$ \\ ${ }^{a}$ University of Thessaly, Department of Agriculture, Crop Production and Rural Environment, 38446 N. Ionia, Magnissia, Greece \\ ${ }^{\mathrm{b}}$ Centro de Investigação de Montanha (CIMO), Instituto Politécnico de Bragança, Campus de Santa Apolónia, 5300-253 Bragança, Portugal \\ ${ }^{\mathrm{c}}$ Cyprus University of Technology, Department of Agricultural Sciences, Biotechnology and Food Science, 3036 Lemesos, Cyprus \\ ${ }^{\mathrm{d}}$ University of Belgrade, Department of Plant Physiology, Institute for Biological Research "Siniša Stanković, Bulevar Despota Stefana 142, 11000 Belgrade, Serbia
}

\section{A R T I C L E I N F O}

\section{Keywords:}

Antimicrobial effects

Antioxidant activity

Cardoon

Cynara cardunculus L.

Cytotoxicity

Globe artichoke

Nutritional value

Phenolic compounds

\begin{abstract}
A B S T R A C T
In the present study, the nutritional value, bioactive properties, and chemical composition of various cardoon (Cynara cardunculus L.) genotypes cultivated in central Greece were investigated. The results demonstrated that Cynara seeds are a good source of fat and protein, while they also contain considerable amounts of $\mathrm{K}, \mathrm{Mg}$, and Fe and low amount of Na. Sucrose, oxalic acid, and $\alpha$-tocopherol were the only free sugar, organic acid, and tocopherol isoform respectively, found among the studied genotypes. The most abundant fatty acids were linoleic, oleic and palmitic acid, while PUFA was the most abundant fatty acid class. All the tested seeds contained only two phenolic compounds, namely 5-O-caffeoylquinic acid and 3,5-O-caffeoylquinic acid, while significant antioxidant activities and cytotoxicity against tumor cell lines and antimicrobial effects were also observed. In conclusion, cardoon seed extracts could be exploited in the food and pharmaceutical industries as alternative sources of natural compounds with bioactive properties.
\end{abstract}

\section{Introduction}

Cynara cardunculus $\mathrm{L}$. is a herbaceous perennial species, widely used throughout the centuries for food and medicinal purposes throughout the Mediterranean basin (Petropoulos, Pereira, Tzortzakis, Barros, \& Ferreira, 2018). It is considered a tolerant species that can be suggested as a potential alternative crop for reclaiming and remediating marginal soils (Francaviglia et al., 2016). Moreover, C. cardunculus is a multipurpose crop with the edible parts of the plant being its immature capitula and tender offshoots. However, the rest of the aerial biomass (leaves and stems) has been suggested for other uses, such as animal fodder and energy production (Mancini et al., 2019), and the food industry (Almeida \& Simões, 2018; Llorente, Obregón, Avilés, Caffini, \& Vairo-Cavalli, 2014). Besides, plant rhizomes extracts have been also attributed with significant antioxidant and antimicrobial properties that may find uses in therapeutical and pharmaceutical purposes (Falleh et al., 2008).

Although seeds constitute a small portion of total aerial biomass, several studies have reported their important bioactive properties, mostly due to their high effectiveness in scavenging free radicals (Georgieva et al., 2014). Raccuia, Melilli, Argento, and Scalisi (2013) highlighted the potential of using cardoon whole grains or hulls for alternative purposes due to their high content in phenolic compounds, such as chlorogenic acid, caffeic acid and catechin, while Cajarville, González, Repetto, Alvir, and Rodríguez (2000) suggested the use of seeds for feeding ruminants. Falleh et al. (2008), reported that cardoon seeds contain similar amounts of phenolic compounds, tannins and flavonoids compared to the leaves. In another study, it was also suggested that ethanolic extracts of seeds had higher antioxidant activity than leaves (Georgieva et al., 2014). Similar results have been reported by Khaldi, Chaouachi, Ksouri, and Gazzah (2013) who evaluated polyphenol content of various Tunisian populations of cardoon plant organs and suggested methanolic extracts of seeds have a higher phenolic compound content and antioxidant activity than stems. These antioxidant properties of seed extracts were attributed mostly to hydrolysable polyphenols consisting of tannins, phenolic acids and hydroxycinnamic acids (Durazzo et al., 2013). Moreover, apart from bioactive properties, Cynara seeds (globe artichoke and cardoon) present an important nutritional value due to the significant amounts of protein and crude fiber (Foti et al., 1999).

Globe artichoke is usually cultivated for its edible heads, while cardoon is considered an important energy crop, which is mostly

\footnotetext{
* Corresponding authors at: University of Thessaly, School of Agricultural Sciences, Fytokou Street, 38446, N. Ionia, Magnissia, Greece (S. Petropoulos).

E-mail addresses: spetropoulos@uth.gr (S. Petropoulos), iferreira@ipb.pt (I.C.F.R. Ferreira).
} 
cultivated for its aerial parts (leaves and stems). Moreover, harvesting of artichoke heads ceases at the end of each growing period due to rapid quality degradation of heads meaning that a great number of heads and seeds remain each year in the field unexploited. So far, most of the research studies in the literature focus on evaluating the use of cardoon seeds and seed press cakes for biodiesel and animal feed production, respectively. Therefore, in the present study nutritional value, chemical composition, and antioxidant and antimicrobial properties of Cynara cardunculus seeds were investigated, while the potential of using them for alternative purposes in the food and pharmaceutical industry was also evaluated.

\section{Materials and methods}

\subsection{Plant material}

Seeds of Cynara cardunculus L. genotypes were evaluated regarding their nutritional value, chemical composition and bioactivities. In particular, seeds from six globe artichokes [Cynara cardunculus L. ssp. scolymus (L.) Fiori], two wild artichokes [Cynara cardunculus L. subsp. sylvestris (L.) Fiori], and one cultivated cardoon genotype [Cynara cardunculus L. subsp. altilis DC] were collected from mature heads from plants grown from seeds at the experimental field of the University of Thessaly, whereas in the case of local landraces, seeds were collected in situ from the regions where they are cultivated. Samples of seeds were obtained from fifteen fully productive plants (one mature inflorescence per plant; $n=15$ ) at the 8th principal growth stage (code stage 89 ), as has been previously described by Petropoulos et al. (2018). Details about the locations where seeds were collected and capitula description of the studied genotypes AS1-AS3 and AS5-AS9 have been reported in previous publications of the authors (Petropoulos et al., 2017, 2018). In brief, the studied genotypes included: a) Greek globe artichoke cultivar cv. "Argitiki" (sample AS1; collected in situ); b) local landrace of globe artichoke with dark purple round heads (sample AS2; collected in situ); c) commercial globe artichoke cultivar with green round heads (Sample AS3; collected from the experimental field); d) wild globe artichoke ecotype with green small round heads and bracts with big spines (sample AS5; collected from the experimental field); e) commercial globe artichoke cultivar with dark purple oblong heads and bracts with small spines (sample AS6; collected from the experimental field); f) Greek globe artichoke cultivar cv. "Purple of Attika" (sample AS7; collected from the experimental field); g) wild globe artichoke ecotype with green small flat round heads and bracts with small spines (sample AS8; collected from the experimental field), and h) commercial cardoon cultivar cv. Biango Avorio (AS9; collected from the experimental field). Seeds from local landrace "Nemea" (sample AS4), which forms green oblong heads with bracts having big spines were collected in situ from the region of Corinthia Prefecture (latitude $37^{\circ} 80^{\prime} 92^{\prime \prime}$, longitude $22^{\circ}$ $\left.65^{\prime} 21^{\prime \prime}\right)$. Before analyses, seed samples were prepared according to the procedure described by Petropoulos et al. (2017). Briefly, seeds were collected from mature inflorescences, ground with a hydro-cooled ball mill (M20 Universal Mill, IKA ${ }^{\circledR}$-Werke GmbH \& Co. KG, Germany), lyophilized, closed in sealed plastic bags and stored until further analysis at $-80^{\circ} \mathrm{C}$.

\subsection{Standards and reagents}

Acetonitrile (99.9\%), $n$-hexane (95\%) and ethyl acetate $(99.8 \%)$ were High Pressure Liquid Chromatography (HPLC) grade from Fisher Scientific (Lisbon, Portugal). The water was obtained from a purification system, Millipore Direct-Q (TGI Pure Water Systems, Greenville, SC, USA). Fatty acid methyl esters standard mixture (standard 47885U) were purchased from Sigma-Aldrich (St. Louis, MO, USA), as also were other standards: sugars, tocopherols, organic acids and Trolox (6hydroxy-2,5,7,8-tetramethylchroman-2-carboxylic acid). Phenolic compounds were purchased from Extrasynthèse (Genay, France).
Racemic tocol was purchased from Matreya (Pleasant Gap, PA, USA). 2,2-Diphenyl-1-picrylhydrazyl (DPPH) was obtained from Alfa Aesar (Ward Hill, MA, USA). Foetal bovine serum (FBS), L-glutamine, hank's balanced salt solution (HBSS), trypsin-EDTA (ethylenediaminetetraacetic acid), penicillin/streptomycin solution $(100 \mathrm{U} / \mathrm{ml}$ and $100 \mathrm{mg} / \mathrm{ml}$, respectively), RPMI-1640 and DMEM media were from Hyclone (Logan, USA). Acetic acid, ellipticine, sulphorhodamine B (SRB), trypan blue, trichloroacetic acid (TCA) and Tris were from Sigma Chemical Co. (St Louis, MO, USA). All other chemicals and solvents were of analytical grade and purchased from common sources.

\subsection{Chemical composition analyses}

\subsubsection{Nutritional value}

Nutritional value of seed samples was assessed by determining moisture, protein, fat, carbohydrates, and ash composition, following AOAC procedures (AOAC, 2016). Briefly, the macronutrient content was determined by the macro-Kjeldahl $(\mathrm{N} \times 6.25)$ method, petroleum ether Soxhlet extraction, and incineration $\left(600^{\circ} \mathrm{C}\right)$, for moisture, protein, and fat, respectively. The carbohydrate amount was determined by difference, and the energetic value was estimated by applying the formula: Energy (kcal/100 g d.w.) $=4 \times(\mathrm{g}$ protein $/ 100 \mathrm{~g}$ d.w. $+\mathrm{g}$ carbohydrate $/ 100 \mathrm{~g} \mathrm{~d}$.w. $)+9 \times(\mathrm{g}$ fat $/ 100 \mathrm{~g}$ d.w. $)$. The results were expressed in $\mathrm{g} / 100 \mathrm{~g}$ d.w.

\subsubsection{Free sugars}

Free sugars were analyzed by HPLC coupled to a refraction index detector (RI) (Barros et al., 2013). Seeds were subjected to an extraction procedure in a water bath $\left(80^{\circ} \mathrm{C} ; 30 \mathrm{~min}\right)$ with ethanol $(80 \% ; 40 \mathrm{ml})$, with the addition of melezitose $(5 \mathrm{mg} / \mathrm{ml})$ as IS. After centrifugation, the supernatant was filtered, concentrated under reduced pressure $\left(60^{\circ} \mathrm{C}\right)$; and defatted with ethyl ether $(10 \mathrm{ml}$; three times). The extract was then centrifuged and concentrated $\left(40^{\circ} \mathrm{C}\right)$ to be re-dissolved in water ( $5 \mathrm{ml}$ final volume) and filtered for injection ( $0.2 \mu \mathrm{m}$ nylon filters from Whatman) in a HPLC-RI system. The HPLC consisted of an integrated equipment with a pump (Knauer, Smartline system 1000, Berlin, Germany), degasser (Smartline manager 5000), auto-sampler (AS-2057 Jasco, Easton, MD, USA), and an RI detector (Knauer Smartline 2300). Data was analyzed using Clarity 2.4 Software (DataApex). The chromatographic separation was achieved with a Eurospher 100-5 $\mathrm{NH}_{2}$ column $(4.6 \times 250 \mathrm{~mm}, 5 \mu \mathrm{m}$, Knauer $)$ operating at $30{ }^{\circ} \mathrm{C}$ (7971 R Graceoven). The mobile phase was acetonitrile/deionized water, $70: 30(\mathrm{v} / \mathrm{v})$ at a flow rate of $1 \mathrm{ml} / \mathrm{min}$. The identification was carried out by comparison with authentic standard retention times, while quantification was achieved using the IS method (DataApex, Podohradska, Czech Republic), by comparing with calibration curves constructed from authentic standards. The results were expressed in $\mathrm{g} /$ $100 \mathrm{~g}$ d.w.

\subsubsection{Organic acids}

Organic acids were analyzed according to the method of Barros et al. (2013). In brief, seed samples ( $2 \mathrm{~g}$ ) were subjected to an extraction with meta-phosphoric acid ( $25 \mathrm{ml} ; 25^{\circ} \mathrm{C} ; 150 \mathrm{rpm}$; $\left.45 \mathrm{~min}\right)$, and filtered through Whatman No. 4 paper and $0.2 \mu \mathrm{m}$ nylon filters before injection. The analysis was performed using a Shimadzu 20A series UFLC (Shimadzu Corporation, Kyoto, Japan). Separation was achieved on a SphereClone (Phenomenex, Torrance, CA, USA) reverse phase $\mathrm{C}_{18}$ column $(5 \mu \mathrm{m}, 250 \mathrm{~mm} \times 4.6 \mathrm{~mm}$ i.d. $)$ thermostatted at $35^{\circ} \mathrm{C}$. The elution was performed with sulphuric acid $(3.6 \mathrm{mM})$ using a flow rate of $0.8 \mathrm{ml} / \mathrm{min}$. Detection was carried out in a PDA, using 215 and $245 \mathrm{~nm}$ (for ascorbic acid) as preferred wavelengths. The organic acids found were quantified by comparison of the area of their peaks recorded at 215 and $245 \mathrm{~nm}$ with calibration curves obtained from commercial standards of each compound. The results were expressed in $\mathrm{mg}$ per $100 \mathrm{~g}$ of dry weight (dw).

For quantification, standard compounds were used to construct 
calibration curves and the peak areas were compared.

\subsubsection{Tocopherols}

Tocopherols were analyzed according to the method of Pereira, Barros, Carvalho, and Ferreira (2013). In brief, BHT (10 mg/ml; $100 \mu \mathrm{l})$ and internal standard (IS; tocol; $50 \mu \mathrm{g} / \mathrm{ml} ; 400 \mu \mathrm{l}$ ) solutions, prepared with hexane, were added to seed samples. The extraction procedure consisted of successively adding methanol $(4 \mathrm{ml})$, hexane $(4 \mathrm{ml})$, and saturated $\mathrm{NaCl}$ aqueous solution $(2 \mathrm{ml})$, with $1 \mathrm{~min}$ vortex mixing between each step. The extract was then centrifuged $(4000 \mathrm{~g} ; 5 \mathrm{~min})$ and the clear upper layer containing tocopherols was collected to a vial, protected from light exposure. The described extraction procedure was repeated twice, with hexane, and the combined extracts were dried under nitrogen stream. To perform the analysis, the dried extracts were re-dissolved in $n$-hexane $(2 \mathrm{ml})$, passed through a sodium sulphate anhydrous micro-column, and filtered $(0.2 \mu \mathrm{m}$ nylon filters from Whatman) to a dark injection vial. The results were expressed in $\mathrm{mg} /$ 100 g d.w.

\subsubsection{Mineral content}

Mineral composition analysis was performed in forced-air dried (at $72{ }^{\circ} \mathrm{C}$ ) and ground to powder seeds, after dry ashing and extraction with $1 \mathrm{~N} \mathrm{HCl}$. Atomic absorption spectrophotometry (Perkin Elmer 1100B, Waltham, MA) was used for $\mathrm{Ca}, \mathrm{Mg}, \mathrm{Fe}, \mathrm{Mn}, \mathrm{Zn}$, and $\mathrm{Cu}$ content determination, while flame photometry (Sherwood Model 410, Cambridge, UK) was used for and $\mathrm{Na}$ and $\mathrm{K}$ content determination.

\subsubsection{Fatty acids}

The fatty acid profile was characterized after a transesterification procedure and according to the method previously described by Barros et al. (2013). The fatty acids obtained by Soxhlet extraction were subjected to a methylation process with methanol/sulphuric acid/toluene $(2: 1: 1(\mathrm{v} / \mathrm{v} / \mathrm{v}) ; 5 \mathrm{ml})$ in a water bath $\left(12 \mathrm{~h} ; 50{ }^{\circ} \mathrm{C} ; 160 \mathrm{rpm}\right)$. Deionized water $(3 \mathrm{ml})$ and diethyl ether $(3 \mathrm{ml})$ were added to obtain phase separation and recover the FAME phase, respectively. Sodium sulphate anhydrous micro-columns were used to remove the remaining water. Before injection, the samples were filtered $(0.2 \mu \mathrm{m}$ nylon filter from Whatman) and transferred to a vial with Teflon. FAMEs were then identified through comparison of retention time with standards; Clarity 4.0.1.7 Software (DataApex, Podohradska, Czech Republic) was used.

\subsubsection{Phenolic compounds}

2.3.7.1. Extract preparation. The extracts were prepared by stirring $\left(150 \mathrm{rpm} ; 25^{\circ} \mathrm{C}\right)$ the seed samples $(1 \mathrm{~g})$ and methanol/water $(30 \mathrm{ml}$; $80: 20 \mathrm{v} / \mathrm{v}$ ) for $1 \mathrm{~h}$. The extracts were filtered through Whatman paper No. 4 and the residue was subjected to an additional extraction at the same conditions. Methanol was removed from the combined extracts under reduced pressure (rotary evaporator Büchi R-210, Flawil, Switzerland), and the aqueous phase was frozen and freeze-dried (FeeeZone 4.5, Labconco, Kansas City, MO, USA).

2.3.7.2. Phenolic compounds analysis. To assess the phenolic composition, the different seed extracts were dissolved in methanol/ water $(80: 20 \mathrm{v} / \mathrm{v})$ to a final concentration of $5 \mathrm{mg} / \mathrm{ml}$ and the phenolic profile was obtained using a Dionex Ultimate 3000 UPLC (Thermo Scientific, San Jose, CA, USA) system equipped with a diode array detector (using $280 \mathrm{~nm}$ as the preferred wavelength) coupled to an electrospray ionization mass detector working in negative mode (Linear Ion Trap LTQ XL mass spectrometer, Thermo Finnigan, San Jose, CA, USA) according to the procedure previously described by Bessada, Barreira, Barros, Ferreira, and Oliveira (2016). Briefly, the chromatographic separation was achieved with a Waters Spherisorb S3 ODS- 2 C18 $(3 \mu \mathrm{m}, 4.6 \mathrm{~mm} \times 150 \mathrm{~mm}$, Waters, Milford, MA, USA) column thermostatted at $35{ }^{\circ} \mathrm{C}$. The solvents used were: (A) $0.1 \%$ formic acid in water, (B) acetonitrile. The elution gradient established was isocratic $15 \%$ B ( $5 \mathrm{~min}$ ), 15\% B-20\% B (5 min), 20-25\% B (10 min),
25-35\% B (10 min), 35-50\% B (10 $\mathrm{min})$, and re-equilibration of the column, using a flow rate of $0.5 \mathrm{ml} / \mathrm{min}$. MS detection was carried out using nitrogen as the sheath gas (50 psi), and the system operated with a spray voltage of $5 \mathrm{kV}$, a source temperature of $325^{\circ} \mathrm{C}$, and a capillary voltage of $-20 \mathrm{~V}$. The tube lens offset was kept at a voltage of $-66 \mathrm{~V}$. The full scan covered the mass range from $m / z 100-1500$. The collision energy used was 35 (arbitrary units). Data acquisition was carried out with the Xcalibur ${ }^{\circledast}$ data system (ThermoFinnigan, San Jose, CA, USA).

For phenolic compound identification, the retention time, UV-vis and mass spectrum of a standard compound (5-O-caffeoylquinic acid) were used; in the case where no standard compound was available, a tentative identification was given according to literature data. The quantification was achieved using a standard compound calibration curve $\quad(5-100 \mu \mathrm{g} / \mathrm{ml} ; \quad 5$-O-caffeoylquinic acid $\geq 99 \%$ purity, Extrasynthèse, Genay, France), based on the UV signal. The results were expressed in $\mathrm{mg} / 100 \mathrm{~g}$ d.w.

\subsection{Bioactive properties}

\subsubsection{Antioxidant activity}

The dried extracts obtained in Section 2.3.7 were re-dissolved in methanol/water $(80: 20 \mathrm{v} / \mathrm{v})$ to a concentration of $2 \mathrm{mg} / \mathrm{ml}$, and successive dilutions were made to perform the antioxidant activity assays. Four in vitro tests were applied: DPPH radical-scavenging activity, reducing power, $\beta$-carotene bleaching inhibition, and lipid peroxidation inhibition by thiobarbituric acid reactive substance (TBARS), as previously described by the authors (Petropoulos, Fernandes, Barros, Ferreira, \& Ntatsi, 2015).

\subsubsection{Cytotoxicity}

Cytotoxicity was evaluated through the sulforhodamine B assay, as previously described by Guimarães et al. (2013), in four tumor cell lines, namely cervical carcinoma (HeLa), hepatocellular carcinoma (HepG2), breast carcinoma (MCF-7), and non-small cell lung cancer (NCI-H460), and in a non-tumor liver primary culture (PLP2). For that purpose, the dried extracts described in Section 2.3.7 were dissolved to a final concentration of $8 \mathrm{mg} / \mathrm{ml}$ and further diluted to perform the assay.

\subsubsection{Antimicrobial activity}

For antimicrobial activity evaluation, the extracts described in the previous Section 2.3.7 were re-dissolved in DMSO 5\% to a concentration of $30 \mathrm{mg} / \mathrm{ml}$ and further diluted.

Antimicrobial activity assays were carried out using Gram-negative bacteria: Escherichia coli (ATCC 35210), Salmonella typhimurium (ATCC 13311), Enterobacter cloacae (ATCC 35030), and Gram-positive bacteria: Staphylococcus aureus (ATCC 6538), Bacillus cereus (clinical isolate), and Listeria monocytogenes (NCTC 7973), following a previously described procedure (Soković, Glamočlija, Marin, Brkić, \& van Griensven, 2010).

Antifungal activity was assessed against Aspergillus fumigatus (ATCC 1022), Aspergillus ochraceus (ATCC 12066), Aspergillus niger (ATCC 6275), Penicillium funiculosum (ATCC 36839), Penicillium ochrochloron (ATCC 9112), and Penicillium verrucosum var. cyclopium (food isolate), following the procedure previously described by the authors (Soković \& Van Griensven, 2006).

\subsection{Statistical analysis}

For each genotype, three batch samples seed $(n=3)$ were analyzed and all the assays were carried out in triplicate. Data were analyzed with one-way analysis of variance (ANOVA), while means comparison was performed with the Tukey's HSD Test $(p=0.05)$. The statistical package Statgraphics 5.1.plus (Statistical Graphics Corporation) was implemented for all the analyses. 
Table 1

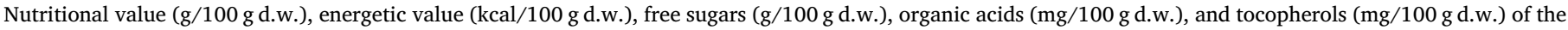
studied Cynara cardunculus L. seeds (mean \pm SD).

\begin{tabular}{|c|c|c|c|c|c|c|c|c|c|}
\hline Sample & Moisture & Fat & Proteins & Ash & Carbohydrates & Energy & Sucrose & Oxalic acid & $\alpha$-Tocopherol \\
\hline AS1 & $6.5 \pm 0.2 \mathrm{~d}$ & $18.8 \pm 0.5 \mathrm{e}$ & $29.9 \pm 0.3 b$ & $3.76 \pm 0.05 a$ & $47.5 \pm 0.8 \mathrm{f}$ & $479 \pm 2 f$ & $0.44 \pm 0.01 c$ & $304 \pm 4 a$ & $1.83 \pm 0.06 \mathrm{~h}$ \\
\hline AS2 & $7.0 \pm 0.3 c$ & $18.4 \pm 0.3 \mathrm{ef}$ & $26.89 \pm 0.08 \mathrm{f}$ & $3.11 \pm 0.09 c$ & $51.6 \pm 0.2 b$ & $480 \pm 1 f$ & $0.45 \pm 0.01 b c$ & $158 \pm 6 h$ & $1.94 \pm 0.03 \mathrm{~g}$ \\
\hline AS3 & $6.7 \pm 0.1 d$ & $18.2 \pm 0.3 f$ & $29.21 \pm 0.04 c$ & $3.4 \pm 0.2 b$ & $49.2 \pm 0.1 \mathrm{e}$ & $477 \pm 2 f$ & $0.42 \pm 0.01 d$ & $143.0 \pm 0.5 \mathrm{i}$ & $3.79 \pm 0.07 c$ \\
\hline AS4 & $8.0 \pm 0.4 a$ & $17.3 \pm 0.9 \mathrm{~g}$ & $28.84 \pm 0.06 d$ & $3.85 \pm 0.09 a$ & $50.1 \pm 0.7 d$ & $471 \pm 3 g$ & $0.46 \pm 0.01 b$ & $239 \pm 2 b$ & $1.21 \pm 0.01 \mathrm{i}$ \\
\hline AS5 & $5.6 \pm 0.1 \mathrm{e}$ & $20.1 \pm 0.1 c$ & $26.1 \pm 0.1 \mathrm{~g}$ & $2.77 \pm 0.07 d$ & $51.1 \pm 0.1 c$ & $489.4 \pm 0.5 d$ & $0.30 \pm 0.01 \mathrm{f}$ & $180.6 \pm 0.2 f$ & $3.49 \pm 0.02 d$ \\
\hline AS6 & $7.6 \pm 0.3 b$ & $22.25 \pm 0.01 b$ & $27.12 \pm 0.3 \mathrm{e}$ & $3.9 \pm 0.2 \mathrm{a}$ & $46.7 \pm 0.1 \mathrm{~g}$ & $495.8 \pm 0.6 c$ & $0.40 \pm 0.01 \mathrm{e}$ & $233.8 \pm 0.1 c$ & $3.35 \pm 0.04 \mathrm{e}$ \\
\hline AS7 & $5.3 \pm 0.1 \mathrm{f}$ & $22.7 \pm 0.2 b$ & $30.4 \pm 0.1 \mathrm{a}$ & $2.8 \pm 0.1 d$ & $44.0 \pm 0.3 \mathrm{i}$ & $502.3 \pm 0.4 b$ & $0.40 \pm 0.01 \mathrm{e}$ & $221 \pm 1 d$ & $3.92 \pm 0.01 b$ \\
\hline AS8 & $5.2 \pm 0.4 \mathrm{f}$ & $19.5 \pm 0.5 d$ & $25.7 \pm 0.1 \mathrm{~h}$ & $2.67 \pm 0.05 d$ & $52.2 \pm 0.3 a$ & $487 \pm 2 e$ & $0.40 \pm 0.01 \mathrm{e}$ & $188 \pm 8 \mathrm{e}$ & $4.46 \pm 0.01 a$ \\
\hline AS9 & $5.1 \pm 0.1 \mathrm{f}$ & $23.7 \pm 0.3 a$ & $29.14 \pm 0.06 c$ & $2.0 \pm 0.1 \mathrm{e}$ & $45.1 \pm 0.3 h$ & $510.6 \pm 0.6 a$ & $0.51 \pm 0.01 \mathrm{a}$ & $163 \pm 1 g$ & $3.18 \pm 0.01 \mathrm{f}$ \\
\hline
\end{tabular}

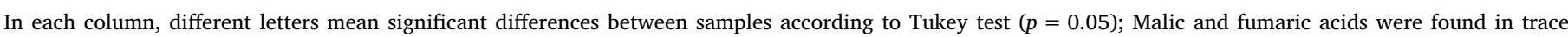
amounts (below LOQ).

\section{Results and discussion}

Results regarding the nutritional value of the tested cardoon genotypes are presented in Table 1. Moisture content of seeds ranged between 5.1\% (AS9; cultivated cardoon) and 8.0\% (AS4; local landrace "Nemea"), with significant differences among the tested genotypes. Seeds contained significant amount of carbohydrates, which consisted of 44.0-52.2 g/ $100 \mathrm{~g}$ d.w., while they were also rich sources of fat and protein with contents ranging between 17.3 and $23.7 \mathrm{~g} / 100 \mathrm{~g}$ d.w. and $25.7-30.4 \mathrm{~g} / 100 \mathrm{~g}$ d.w., respectively. The highest energetic value was observed for AS9 due to its highest content of fat (23.7 g/100 g d.w.), whereas AS4 had the lowest energy due to high moisture content $(8.0 \%)$. The results of our study are in the same range in terms of dry matter and crude protein content with the report of Cajarville et al. (2000) who evaluated the potential of using cardoon seeds as feed for ruminants. Similar moisture contents to our study were observed by Maccarone, Fallico, Fanella, Mauromicale, and Raccuia (1999) and Foti et al. (1999) who also observed differences between globe artichoke, and wild and cultivated cardoon genotypes, while Raccuia and Melilli (2007) suggested that harvesting year and growing conditions may also have an effect on moisture and oil content of cardoon seeds. Moreover, Nouraei, Rahimmalek, Saeidi, and Bahreininejad (2016) reported a significant effect of irrigation regime on seed oil content of globe artichoke seeds with decreasing water availability, resulting in lower oil yields. Considering the perennial nature of the species, the age of plants (years after establishment) is also essential for the production of extended roots system that allows for exploitation of deeper water pools in soil.

Free sugar, organic acid and tocopherol composition is presented in Table 1. Sucrose was the only detected free sugar with significant differences between the tested genotypes being observed $(0.30$ and $0.51 \mathrm{~g} /$ $100 \mathrm{~g}$ d.w. for AS5 and AS9, respectively). Moreover, oxalic acid was the only organic acid identified (143-304 mg/100 g d.w. for AS3 and AS1, respectively), whereas traces of malic and fumaric acids were detected. Oxalic acid is considered as an antinutrient factor and its high dietary intake is not recommended on a regular basis due to increased risk for the development of calcium oxalate crystals and kidney stones (Moreau \& Savage, 2009); however, the detected amounts in our study were within safe limits and lower than other edible species, which are considered as rich sources of oxalic acid (Petropoulos et al., 2015). Therefore, consumption of cardoon seeds should be considered as safe, especially when accounting for their low intake on a daily basis. The only tocopherol isoform detected was $\alpha$-tocopherol in amounts that ranged between $1.21 \mathrm{mg} / 100 \mathrm{gd} . \mathrm{w}$. (AS4) and $4.46 \mathrm{mg} / 100 \mathrm{gd}$.w. (AS8). Therefore, the amount of total free sugars, organic acids, and tocopherols correspond to the amounts of the individual compounds (sucrose, oxalic acid, and $\alpha$-tocopherol, respectively). To the best of our knowledge, the free sugar, organic acid, and tocopherol content in Cynara seeds is reported for the first time. So far, only seed oil composition has been characterized with $\alpha$-tocopherol being the main tocopherol detected in Cynara cardunculus L. seed oil by Ferreira-Dias, Gominho, Baptista, and Pereira (2018), followed by $\delta$ - and $\gamma$-tocopherol, whereas Maccarone et al. (1999) detected only $\alpha$-tocopherol in grain oils from different Cynara spp. Genotypes, including globe artichoke and wild and cultivated cardoon. According to Zonta and Stancher (1983), tocopherols are very labile compounds and susceptible to oxidation during post-harvest treatments, which could explain the lack of various tocopherol isoforms in seeds and the differences between the reports in the literature.

Mineral content is presented in Table 2, with significant differences being observed between the tested genotypes. Significant amounts of K, $\mathrm{Ca}, \mathrm{Mg}$ and Fe were detected in all the tested seeds, while the $\mathrm{Na}$ content was considerably low $(12-24 \mathrm{mg} / 100 \mathrm{~g}$ d.w.), which is considered a very important feature from a nutritional point of view, especially for people who follow diets low in Na. Similar values for all the determined minerals have been reported in cultivated cardoon seeds from our team for the same plants harvested a year before the plants of the present study (Petropoulos et al., 2018), which indicates that in seeds from well-established and fully productive plants, variations in mineral content are mostly due to growing conditions.

Table 2

Mineral composition (mg/100 g d.w.) of the studied Cynara cardunculus L. seeds (mean \pm SD).

\begin{tabular}{|c|c|c|c|c|c|c|c|}
\hline Sample & $\mathrm{K}$ & $\mathrm{Na}$ & $\mathrm{Ca}$ & $\mathrm{Mg}$ & $\mathrm{Mn}$ & $\mathrm{Fe}$ & $\mathrm{Zn}$ \\
\hline AS1 & $640 \pm 18 b c$ & $14 \pm 1 \mathrm{~cd}$ & $1201 \pm 193 b c$ & $474 \pm 11 b c$ & $4.9 \pm 0.1 c$ & $9.2 \pm 0.5 f$ & $3.6 \pm 0.4 \mathrm{~d}$ \\
\hline AS2 & $880 \pm 60 a$ & $12 \pm 1 d$ & $734 \pm 52 d$ & $355 \pm 24 c d$ & $4.21 \pm 0.02 \mathrm{~d}$ & $12 \pm 2 c$ & $3.9 \pm 0.4 \mathrm{~cd}$ \\
\hline AS3 & $667 \pm 46 b$ & $19 \pm 2 b$ & $971 \pm 72 \mathrm{~cd}$ & $545 \pm 77 b c$ & $4.74 \pm 0.08 c$ & $12 \pm 2 c$ & $4.9 \pm 0.2 \mathrm{ab}$ \\
\hline AS4 & $560 \pm 53 c d$ & $19 \pm 2 b$ & $1583 \pm 75 a$ & $809 \pm 88 a$ & $5.6 \pm 0.5 b$ & $9.6 \pm 0.4 f$ & $4.8 \pm 0.4 \mathrm{ab}$ \\
\hline AS5 & $593 \pm 81 b c d$ & $24 \pm 5 a$ & $1047 \pm 164 c$ & $241 \pm 17 d$ & $4.6 \pm 0.8 \mathrm{~cd}$ & $11.6 \pm 0.6 \mathrm{~d}$ & $1.4 \pm 0.4 \mathrm{e}$ \\
\hline AS6 & $680 \pm 72 b$ & $19 \pm 3 b$ & $1235 \pm 288 b c$ & $665 \pm 78 \mathrm{ab}$ & $5.96 \pm 0.10 \mathrm{a}$ & $10.5 \pm 0.9 \mathrm{e}$ & $5.2 \pm 0.4 \mathrm{a}$ \\
\hline AS7 & $520 \pm 35 d$ & $17 \pm 1 b$ & $1243 \pm 181 b c$ & $597 \pm 54 a b$ & $6.2 \pm 0.2 \mathrm{a}$ & $14 \pm 1 b$ & $4.5 \pm 0.6 b c$ \\
\hline AS8 & $633 \pm 61 b c$ & $19 \pm 2 b$ & $1353 \pm 115 a b$ & $489 \pm 36 b c$ & $5.95 \pm 0.09 a$ & $16 \pm 1 \mathrm{a}$ & $3.7 \pm 0.4 d$ \\
\hline AS9 & $493 \pm 11 \mathrm{e}$ & $19 \pm 3 b$ & $735 \pm 40 \mathrm{e}$ & $388 \pm 58 \mathrm{~cd}$ & $5.63 \pm 0.03 b$ & $11.48 \pm .08 \mathrm{~d}$ & $3.3 \pm 0.5 d$ \\
\hline
\end{tabular}

In each column, different letters mean significant differences between samples according to Tukey test $(p=0.05)$. 


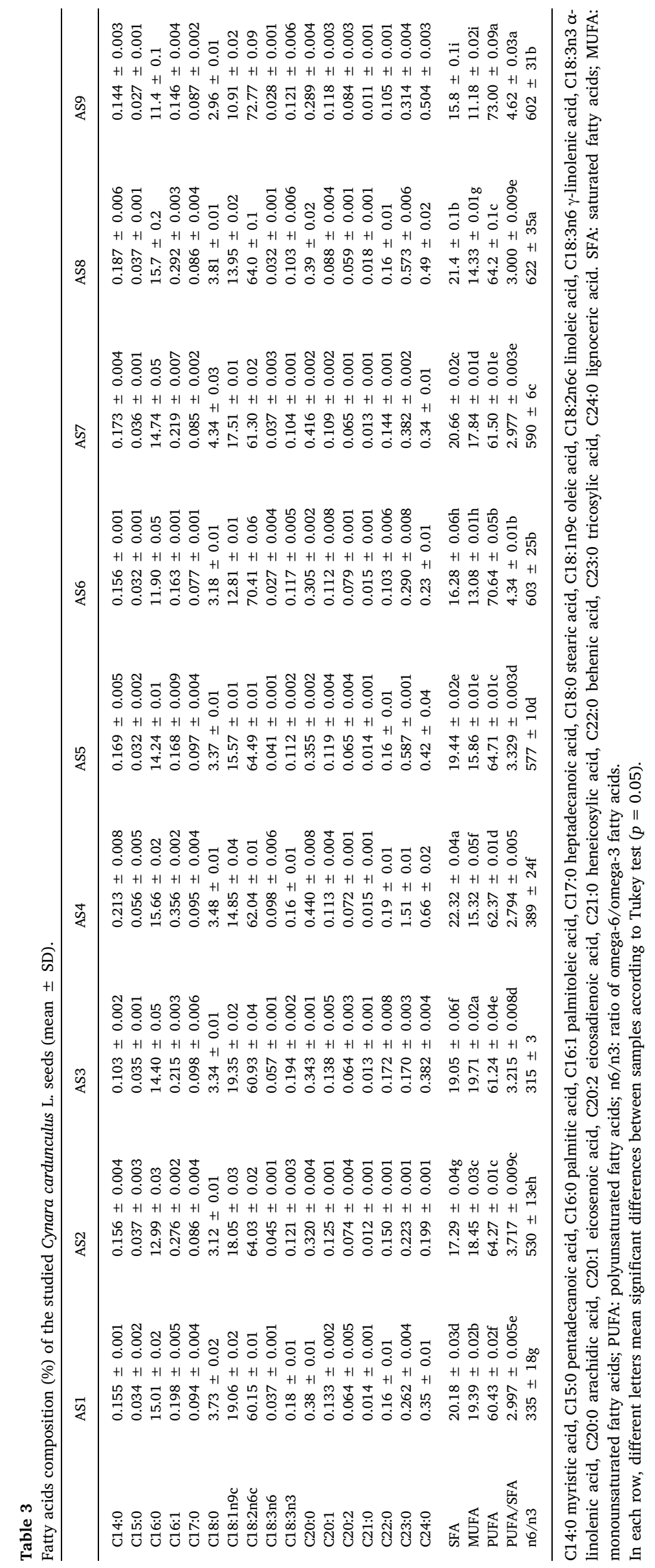


Moreover, the ratio of oxalic acid (mg/100 g d.w.)/Ca (mg/100 g d.w.) is higher than 2.5 for all the studied genotypes, which indicates that despite its high Ca content Cynara seeds can be considered as poor $\mathrm{Ca}$ sources or decalcifiers (Guil, Torija, Giménez, Rodríguez-García, \& Himénez, 1996) and further studies regarding bioavailability and bioaccesibility of $\mathrm{Ca}$ after digestion have to be carried out.

Regarding the fatty acid composition of seeds (Table 3), 17 individual fatty acids were detected in all the studied genotypes, while the most abundant ones were linolenic $(60.15 \%-72.77 \%)$, oleic (10.91\%-19.35\%) and palmitic acid (11.4\%-15.7\%) all accounting for more than $92.05 \%$ of total fatty acids. The highest amount of linoleic acid was detected in seeds of the AS9 genotype, while the highest contents of oleic and palmitic acid were recorded in AS3 and AS4 genotypes, respectively. A similar composition of fatty acids for cultivated cardoon seeds has been previously reported by our team, where a significant effect of harvesting year was also observed (Petropoulos et al., 2018). To the best of our knowledge, this is the first report regarding fatty acid composition of globe artichoke seeds, since most of the studies refer to seed oils of Cynara cardunculus $\mathrm{L}$.

Polyunsaturated fatty acids (PUFA) were the most abundant class of fatty acids, followed by saturated (SFA) and monounsaturated fatty acids (MUFA) detected in similar amounts, while the ratio of PUFA/SFA was higher than 0.45 for all the tested seeds, which is an important nutritional parameter of food products (Simopoulos, 1997). Petropoulos et al. (2018) have also reported high ratios of n-6/n-3 fatty acids in cardoon seeds harvested in two consecutive years, although these values were lower than those reported in the present study mostly due to the lower amounts of n-3 fatty acids. Moreover, the very low amounts of n-3 fatty acids and $\alpha$-linolenic acid in particular, resulted in very high ratios of $n-6 / n-3$ fatty acids. This finding implies that low amounts of seeds have to be consumed on a daily basis or its consumption has to be followed by supplementary sources of n-3 fatty acids in order to avoid high cumulative intake of n- 6 fatty acids and its negative health effects (Simopoulos, 2008).

The phenolic composition of the tested seeds is presented in Table 4. Only two individual phenolic compounds were detected in all the studied seed extracts, namely 5-O-caffeoylquinic acid and 3,5-O-caffeoylquinic acid (Supplementary Material Fig. S1).

5-O-Caffeoylquinic acid was positively identified in comparison with the commercial standard. While 3,5-O-caffeoylquinic acid $\left([\mathrm{M}-\mathrm{H}]^{-}\right.$at $\left.m / z 515\right)$ was identified based on its elution order, fragmentation pattern and relative abundances in comparison with those reported by Clifford, Knight, and Kuhnert (2005).

The amounts of these two phenolic acids ranged between 22.5 and $35.8 \mathrm{mg} / 100 \mathrm{gd} . w$. and $197-418 \mathrm{mg} / 100 \mathrm{gd}$.w., respectively. The highest amounts of total phenolic compounds were detected in seeds of the AS9 genotype (435 mg/100 g d.w.), mostly due to the highest content in 3,5-O-caffeoylquinic acid $(418 \mathrm{mg} / 100 \mathrm{~g} \mathrm{~d} . w$.). The same phenolic compounds have been previously reported by Petropoulos et al. (2018) who studied phenolic compound composition of cultivated cardoon plant parts. In contrast, Falleh et al. (2008) detected both polyphenols and flavonoids in cardoon seeds without however identifying individual compounds, while they also suggested that seeds contained similar amounts of polyphenols and flavonoids to leaf extracts. Moreover, Khaldi et al. (2013) detected polyphenols and flavonoids in wild cardoon seeds in amounts that differed depending on growing region. These differences in phenolic compound composition compared to the literature reports could be attributed to extraction methodology (Brás, Guerreiro, Duarte, \& Neves, 2015), as well as to genotype and growing conditions (Lombardo et al., 2010).

Antioxidant activity and cytotoxicity of seed extracts are presented in Table 5. Antioxidant activity determined with multiple in vitro assays showed significant differences among the tested genotypes. In particular, genotype AS1 showed the best results in the DPPH and $\beta$-carotene bleaching inhibition assays, while extracts from AS2 and AS4 seeds had the best antioxidant properties for reducing power and

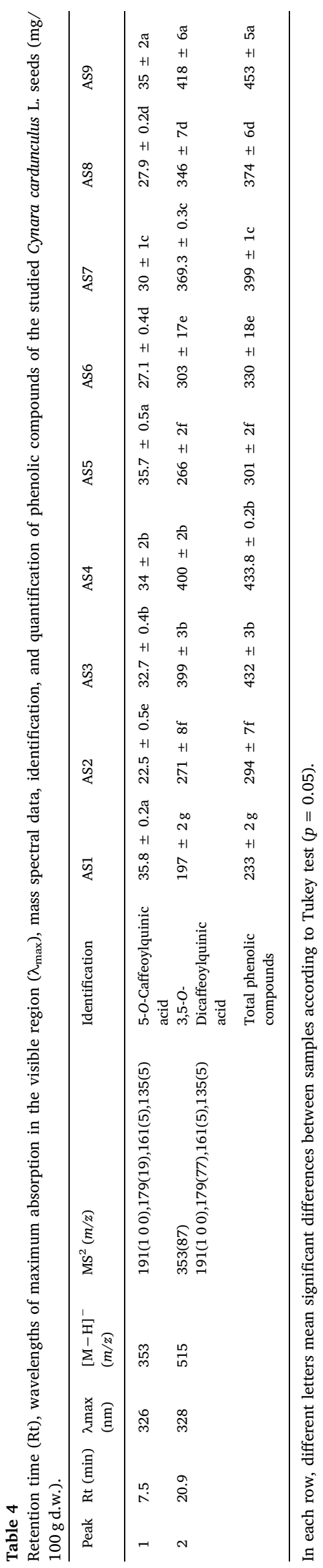


Table 5

Antioxidant activity ( $\mathrm{EC}_{50}$ values, $\left.\mu \mathrm{g} / \mathrm{ml}\right)$ and cytotoxicity $\left(\mathrm{GI}_{50}\right.$ values, $\left.\mu \mathrm{g} / \mathrm{ml}\right)$ of the studied Cynara cardunculus $\mathrm{L}$. seeds (mean $\pm \mathrm{SD}$ ).

\begin{tabular}{|c|c|c|c|c|c|c|c|c|c|}
\hline Antioxidant activity $\left(\mathrm{EC}_{50}\right.$ values, $\mu \mathrm{g} / \mathrm{ml}$ ) & AS1 & AS2 & AS3 & AS4 & AS5 & AS6 & AS7 & AS8 & AS9 \\
\hline DPPH scavenging activity & $103 \pm 4 h$ & $176 \pm 2 f$ & $260 \pm 1 b$ & $223 \pm 6 d$ & $380 \pm 4 a$ & $215 \pm 5 e$ & $237 \pm 6 c$ & $239 \pm 3 c$ & $159 \pm 2 g$ \\
\hline$\beta$-carotene bleaching inhibition & $156 \pm 4 a$ & $82 \pm 1 g$ & $114 \pm 1 d$ & $102 \pm 1 \mathrm{e}$ & $145 \pm 3 b$ & $145 \pm 1 b$ & $121 \pm 6 c$ & $98 \pm 3 f$ & $99 \pm 1 \mathrm{f}$ \\
\hline Reducing power & $79 \pm 7 g$ & $470 \pm 15 d$ & $571 \pm 27 a$ & $394 \pm 7 f$ & $385 \pm 18 f$ & $445 \pm 15 \mathrm{e}$ & $584 \pm 21 a$ & $519 \pm 5 c$ & $543 \pm 17 b$ \\
\hline TBARS inhibition & $254 \pm 10 \mathrm{~b}$ & $53 \pm 2 f$ & $50 \pm 2 f$ & $37 \pm 1 g$ & $266 \pm 8 a$ & $153 \pm 5 e$ & $176 \pm 7 d$ & $185 \pm 6 c$ & $254 \pm 12 b$ \\
\hline \multicolumn{10}{|c|}{ Cytotoxicity to tumor cell lines ( $\mathrm{GI}_{50}$ values, $\mu \mathrm{g} / \mathrm{ml}$ ) } \\
\hline HeLa (cervical carcinoma) & $237 \pm 18 d$ & $278 \pm 8 b$ & $>400$ & $324 \pm 7 a$ & $>400$ & $>400$ & $251 \pm 5 c$ & $274 \pm 7 b$ & $259 \pm 6 c$ \\
\hline HepG2 (hepatocellular carcinoma) & $212 \pm 20 f$ & $312 \pm 21 b$ & $>400$ & $348 \pm 9 a$ & $>400$ & $>400$ & $253 \pm 7 d$ & $267 \pm 13 c$ & $241 \pm 4 \mathrm{e}$ \\
\hline MCF-7 (breast carcinoma) & $265 \pm 10 \mathrm{e}$ & $287 \pm 6 c$ & $>400$ & $324 \pm 7 a$ & $>400$ & $>400$ & $277 \pm 6 \mathrm{~d}$ & $297 \pm 8 b$ & $303 \pm 11 b$ \\
\hline NCI-H460 (non-small cell lung cancer) & $323 \pm 5 b$ & $334 \pm 4 a$ & $>400$ & $>400$ & $>400$ & $>400$ & $334 \pm 7 a$ & $339 \pm 4 a$ & $312 \pm 5 c$ \\
\hline \multicolumn{10}{|c|}{ Cytotoxicity to non-tumor cell lines ( $\mathrm{GI}_{50}$ values, $\mu \mathrm{g} / \mathrm{ml}$ ) } \\
\hline PLP2 (porcine liver primary culture) & $>400$ & $>400$ & $>400$ & $>400$ & $>400$ & $>400$ & $>400$ & $>400$ & $>400$ \\
\hline
\end{tabular}

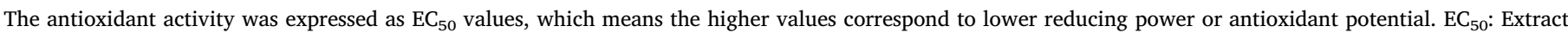

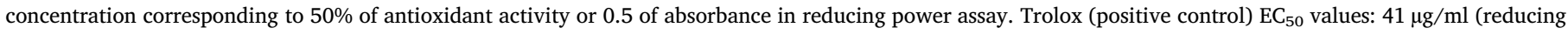

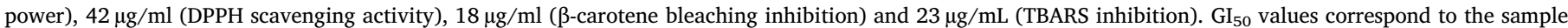

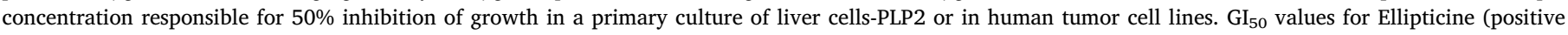

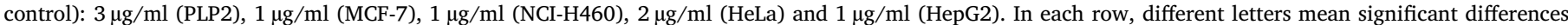
between samples according to Tukey test $(p=0.05)$.

TBARS inhibition assays, respectively. Significant antioxidant activities have been reported by Falleh et al. (2008) in cardoon seed methanolic extracts, while in the same study it was also reported that seed extracts showed a higher DPPH quenching activity and lower $\mathrm{O}_{2}{ }^{-\cdot}$ scavenging activity than leaf extracts. Similarly, in the study of Petropoulos et al. (2018), cultivated cardoon seed hydromethanolic extracts showed higher antioxidant activity for the DPPH and reducing power assays compared to the other plant parts (leaf midribs and petioles, leaf blades, and heads), a finding which was also confirmed by Georgieva et al. (2014) who studied antioxidant activities of ethanolic extracts of cardoon seeds and leaves. Durazzo et al. (2013) have also reported significant differences among globe artichoke and wild and cultivated cardoon genotypes, as well as between hydromethanolic extracts and its residues, while according to Kollia, Markaki, Zoumpoulakis, and Proestos (2016) antioxidant activity of natural matrices may be also affected by extraction techniques.

Regarding in vitro cytotoxicity tests, none of the tested genotypes showed cytotoxicity effects against non-tumor (PLP2) cell lines, since $\mathrm{GI}_{50}$ values were higher than $400 \mu \mathrm{g} / \mathrm{ml}$ for all the seed extracts (Table 5). Moreover, seeds of AS1 had the highest toxicity against HeLa, HepG2, and MCF-7 cell lines, while seed extracts of AS9 were the most efficient against NCI-H640 cell lines. In contrast, AS3, AS5, and AS6 genotypes were the least effective against all the tested tumor cell lines, since seed extracts presented $\mathrm{GI}_{50}$ values $>400 \mu \mathrm{g} / \mathrm{ml}$. To the best of our knowledge, this is the first report regarding the cytotoxic effects of Cynara cardunculus L. seed extracts against tumor cell lines, since so far only our team has presented results regarding the effect of cardoon seed extracts against non-tumor (PLP2) cell lines (Petropoulos et al. (2018). These antiproliferative activities could be partly attributed to the detected phenolic compounds (5-O-caffeoylquinic acid and 3,5-O-caffeoylquinic acid), which according to the literature they have been associated with several health effects, including anticancer activities (Murad, da Soares, Brand, Monteiro, \& Teodoro, 2015).

Cardoon extracts presented significant antimicrobial properties against the tested bacteria and fungi (Table 6). All seed extracts showed higher or similar bactericidal and bacteriostatic activity (MBC and MIC values, respectively) compared to streptomycin and ampicillin against Bacillus aureus, Listeria monocytogenes, and Enterobacter cloacae, as well as against Escherichia coli and Salmonella tympimurium (except for AS5 and AS6, and AS5, respectively). Regarding Staphylococcus aureus, only streptomycin showed better results than any cardoon genotype, whereas ampicillin was less effective than cardoon seeds. The antifungal properties of seed extracts showed a varied response depending on cardoon genotype and the tested fungi. In most cases, MIC and MBC values were lower or similar to control compounds (ketoconazole or bifonazole), while in certain cases specific genotypes showed better results than both control compounds. In particular, genotype AS7 was more effective against Aspergillus fumigatus, AS1, AS4 and AS6 against A. ochraceus, AS6 against A. niger, Penicillium funiculosum, and $P$. verrucosum var. cyclopium, and AS1 against $P$. ochrochloron. So far, the antimicrobial properties of Cynara cardunculus L. refer to various plant parts, such as leaves, flowers, rhizomes and heads (Falleh et al., 2008), with significant effects against bacteria, such as Staphylococcus aureus, Methicillin-resistant Staphylococcus aureus, Bacillus cereus, B. subtilis, Pseudomonas aeruginosa, Enterococcus faecalis, and E. coli, and fungi, such as Aspergillus niger, Penicillium oxalicum, Mucor mucedo, Cladosporium cucumerinum, and Candida albicans. To the best of our knowledge, this is the first report regarding the antimicrobial effects of cardoon seed methanolic extracts. These effects could be apportioned to the detected phenolic compounds (5-O-caffeoylquinic acid and 3,5-Ocaffeoylquinic acid), since literature reports for other plant species highlight the important inhibitory effects of such compounds against various pathogenic bacteria (Fiamegos et al., 2011).

Overall, the differences in bioactive properties of the tested cardoon genotypes should be attributed to genetic aspects, since not all the genotypes were cultivated under the same growing conditions (i.e. AS1, AS2 and AS4 were collected in situ from different regions, whereas AS3 and AS5-AS9 were cultivated under the same conditions). According to the literature, both genetic background and environmental conditions may affect bioactive compound content of Cynara cardunculus, especially caffeoylquinic acids content, and therefore result in significant differences in their bioactive properties (Lombardo et al., 2010; Moglia et al., 2008).

\section{Conclusion}

The results of the present study demonstrated that Cynara seeds are a good source of fat and protein, as well as of macro- and micro nutrients, such as $\mathrm{K}, \mathrm{Mg}$, and $\mathrm{Fe}$, while they also contain a low amount of Na. Sucrose, oxalic acid, and $\alpha$-tocopherol were the only detected free sugar, organic acid, and tocopherol isoform, respectively, identified among the studied genotypes. The main detected fatty acids were linoleic, oleic and palmitic acid, while PUFA were the most abundant fatty acid class resulting in PUFA/SFA ratios higher than 0.45 . Only two phenolic compounds, namely 5-O-caffeoylquinic acid and 3,5-O-caffeoylquinic acid, were identified in the tested seeds, while significant 
Table 6

Antibacterial and antifungal activities of the studied Cynara cardunculus $\mathrm{L}$. seeds (MIC and MBC/MFC, mg/ml).

\begin{tabular}{|c|c|c|c|c|c|c|c|}
\hline Samples & & B. cereus & S. aureus & L. monocytogenes & E. coli & En. cloacae & S. typhimurium \\
\hline \multirow[t]{2}{*}{ AS1 } & MIC & 0.01 & 0.15 & 0.075 & 0.10 & 0.10 & 0.075 \\
\hline & MBC & 0.02 & 0.30 & 0.015 & 0.15 & 0.15 & 0.15 \\
\hline \multirow[t]{2}{*}{ AS2 } & MIC & 0.02 & 0.075 & 0.10 & 0.10 & 0.10 & 0.10 \\
\hline & MBC & 0.04 & 0.15 & 0.15 & 0.15 & 0.15 & 0.15 \\
\hline \multirow[t]{2}{*}{ AS3 } & MIC & 0.01 & 0.075 & 0.075 & 0.075 & 0.075 & 0.15 \\
\hline & MBC & 0.02 & 0.15 & 0.15 & 0.15 & 0.15 & 0.30 \\
\hline \multirow[t]{2}{*}{ AS4 } & MIC & 0.05 & 0.075 & 0.075 & 0.15 & 0.10 & 0.075 \\
\hline & MBC & 0.15 & 0.15 & 0.15 & 0.30 & 0.15 & 0.15 \\
\hline \multirow[t]{2}{*}{ AS5 } & MIC & 0.10 & 0.15 & 0.15 & 0.30 & 0.20 & 0.45 \\
\hline & MBC & 0.15 & 0.30 & 0.30 & 0.60 & 0.30 & 0.60 \\
\hline \multirow[t]{2}{*}{ AS6 } & MIC & 0.01 & 0.15 & 0.15 & 0.15 & 0.075 & 0.075 \\
\hline & MBC & 0.02 & 0.30 & 0.30 & 0.30 & 0.15 & 0.15 \\
\hline \multirow[t]{2}{*}{ AS7 } & MIC & 0.075 & 0.10 & 0.20 & 0.30 & 0.20 & 0.15 \\
\hline & MBC & 0.15 & 0.15 & 0.30 & 0.60 & 0.30 & 0.30 \\
\hline \multirow{2}{*}{ AS8 } & MIC & 0.075 & 0.20 & 0.15 & 0.20 & 0.15 & 0.15 \\
\hline & MBC & 0.15 & 0.30 & 0.30 & 0.30 & 0.30 & 0.30 \\
\hline \multirow[t]{2}{*}{ AS9 } & MIC & 0.075 & 0.15 & 0.15 & 0.15 & 0.15 & 0.15 \\
\hline & MBC & 0.15 & 0.30 & 0.30 & 0.30 & 0.30 & 0.30 \\
\hline \multirow[t]{2}{*}{ Streptomycin } & MIC & 0.10 & 0.04 & 0.20 & 0.20 & 0.20 & 0.20 \\
\hline & MBC & 0.20 & 0.10 & 0.30 & 0.30 & 0.30 & 0.30 \\
\hline \multirow[t]{2}{*}{ Ampicillin } & MIC & 0.25 & 0.25 & 0.40 & 0.40 & 0.25 & 0.75 \\
\hline & MBC & 0.40 & 0.45 & 0.50 & 0.50 & 0.50 & 1.20 \\
\hline \multicolumn{2}{|l|}{ Samples } & A. fumigatus & A. ochraceus & A. niger & P. funiculosum & P. ochrochloron & P. v. cyclopium \\
\hline \multirow[t]{2}{*}{ AS1 } & MIC & 0.10 & 0.075 & 0.15 & 0.075 & 0.04 & 0.075 \\
\hline & MFC & 0.30 & 0.15 & 0.30 & 0.15 & 0.075 & 0.15 \\
\hline \multirow[t]{2}{*}{ AS2 } & MIC & 0.15 & 0.10 & 0.15 & 0.10 & 0.15 & 0.15 \\
\hline & MFC & 0.30 & 0.15 & 0.30 & 0.30 & 0.30 & 0.30 \\
\hline \multirow[t]{2}{*}{ AS3 } & MIC & 0.10 & 0.15 & 0.15 & 0.30 & 0.15 & 0.45 \\
\hline & MFC & 0.30 & 0.30 & 0.30 & 0.60 & 0.30 & 0.60 \\
\hline \multirow[t]{2}{*}{ AS4 } & MIC & 0.15 & 0.075 & 0.15 & 0.075 & 0.10 & 0.075 \\
\hline & MFC & 0.30 & 0.15 & 0.30 & 0.15 & 0.15 & 0.15 \\
\hline \multirow[t]{2}{*}{ AS5 } & MIC & 0.30 & 0.20 & 0.30 & 0.30 & 0.45 & 0.45 \\
\hline & MFC & 0.60 & 0.30 & 0.60 & 0.60 & 0.60 & 0.60 \\
\hline \multirow[t]{2}{*}{ AS6 } & MIC & 0.15 & 0.075 & 0.10 & 0.05 & 0.075 & 0.05 \\
\hline & MFC & 0.30 & 0.15 & 0.15 & 0.15 & 0.15 & 0.15 \\
\hline \multirow[t]{2}{*}{ AS7 } & MIC & 0.05 & 0.15 & 0.20 & 0.20 & 0.075 & 0.075 \\
\hline & MFC & 0.075 & 0.30 & 0.30 & 0.30 & 0.15 & 0.15 \\
\hline \multirow[t]{2}{*}{ AS8 } & MIC & 0.15 & 0.10 & 0.15 & 0.075 & 0.075 & 0.075 \\
\hline & MFC & 0.30 & 0.15 & 0.30 & 0.15 & 0.15 & 0.15 \\
\hline \multirow[t]{2}{*}{ AS9 } & MIC & 0.20 & 0.20 & 0.30 & 0.20 & 0.30 & 0.45 \\
\hline & MFC & 0.60 & 0.30 & 0.60 & 0.45 & 0.60 & 0.60 \\
\hline \multirow[t]{2}{*}{ Ketoconazole } & MIC & 0.25 & 0.20 & 0.20 & 0.20 & 2.50 & 0.20 \\
\hline & MFC & 0.50 & 0.50 & 0.50 & 0.50 & 3.50 & 0.30 \\
\hline Bifonazole & MIC & 0.15 & 0.10 & 0.15 & 0.20 & 0.20 & 0.10 \\
\hline & MFC & 0.20 & 0.20 & 0.20 & 0.25 & 0.25 & 0.20 \\
\hline
\end{tabular}

antioxidant activities and cytotoxicity against tumor cell lines and antimicrobial effects were also observed. In conclusion, cardoon seed extracts showed significant bioactive properties that could be exploited in the food and pharmaceutical industries as alternative sources of antimicrobial agents and natural preservatives, as well as sources of bioactive compounds.

\section{Acknowledgments}

The authors are grateful to the Foundation for Science and Technology (FCT, Portugal) and FEDER under Programme PT2020 for financial support to CIMO (UID/AGR/00690/2013), C. Pereira (SFRH/ BPD/122650/2016), A. Fernandes (SFRH/BPD/114753/2016) grants and L. Barros contract. The authors are also grateful to the FEDERInterreg España-Portugal programme for financial support through the project 0377 Iberphenol_6_E. The authors are grateful to the Ministry of Education, Science and Technological Development of the Republic of Serbia for Grant No. 173032.

\section{Declarations of interest}

None.

\section{Appendix A. Supplementary data}

Supplementary data to this article can be found online at https:// doi.org/10.1016/j.foodchem.2019.03.066.

\section{References}

Almeida, C. M., \& Simões, I. (2018). Cardoon-based rennets for cheese production. Applied Microbiology and Biotechnology, 4675-4686. https://doi.org/10.1007/s00253-0189032-3.

AOAC (2016). Official methods of analysis of AOAC International. In W. Horwitz, \& G. Latimer (Eds.). Official methods of analysis of AOAC international(20th ed.). Gaithersburg, MD: AOAC International.

Barros, L., Pereira, E., Calhelha, R. C., Dueñas, M., Carvalho, A. M., Santos-Buelga, C., \& Ferreira, I. C. F. R. (2013). Bioactivity and chemical characterization in hydrophilic and lipophilic compounds of Chenopodium ambrosioides L. Journal of Functional Foods, 5(4), 1732-1740. https://doi.org/10.1016/j.jff.2013.07.019.

Bessada, S. M. F., Barreira, J. C. M., Barros, L., Ferreira, I. C. F. R., \& Oliveira, M. B. P. P. (2016). Phenolic profile and antioxidant activity of Coleostephus myconis(L.) Rchb.f.: An underexploited and highly disseminated species. Industrial Crops and Products, 89, 45-51. https://doi.org/10.1016/j.indcrop.2016.04.065.

Brás, T., Guerreiro, O., Duarte, M. F., \& Neves, L. A. (2015). Impact of extraction parameters and concentration by nanofiltration on the recovery of phenolic compounds from Cynara cardunculus var. altilis: Assessment of antioxidant activity. Industrial Crops and Products, 67, 137-142. https://doi.org/10.1016/j.indcrop.2015.01.005.

Cajarville, C., González, J., Repetto, J. L., Alvir, M. R., \& Rodríguez, C. A. (2000). 
Nutritional evaluation of cardoon (Cynara cardunculus) seed for ruminants. Animal Feed Science and Technology, 87(3-4), 203-213. https://doi.org/10.1016/S03778401(00)00198-X.

Clifford, M. N., Knight, S., \& Kuhnert, N. (2005). Discriminating between the six isomers of dicaffeoylquinic acid by LC-MSn. Journal of Agricultural and Food Chemistry, 53(10), 3821-3832. https://doi.org/10.1021/jf050046h.

Durazzo, A., Foddai, M., Temperini, A., Azzini, E., Venneria, E., Lucarini, M., ... Maiani, G. (2013). Antioxidant properties of seeds from lines of artichoke, cultivated cardoon and wild cardoon. Antioxidants, 2(2), 52-61. https://doi.org/10.3390/ antiox 2020052

Falleh, H., Ksouri, R., Chaieb, K., Karray-Bouraoui, N., Trabelsi, N., Boulaaba, M., \& Abdelly, C. (2008). Phenolic composition of Cynara cardunculus L. organs, and their biological activities. Comptes Rendus - Biologies, 331(5), 372-379. https://doi.org/10. 1016/j.crvi.2008.02.008.

Ferreira-Dias, S., Gominho, J., Baptista, I., \& Pereira, H. (2018). Pattern recognition of cardoon oil from different large-scale field trials. Industrial Crops and Products, 118(April), 236-245. https://doi.org/10.1016/j.indcrop.2018.03.038.

Fiamegos, Y. C., Kastritis, P. L., Exarchou, V., Han, H., Bonvin, A. M. J. J., Vervoort, J., ... Tegos, G. P. (2011). Antimicrobial and efflux pump inhibitory activity of caffeoylquinic acids from Artemisia absinthium against Gram-positive pathogenic bacteria. PLoS One, 6(4), 1-12. https://doi.org/10.1371/journal.pone.0018127.

Foti, S., Mauromicale, G., Raccuia, S. A., Fallico, B., Fanella, F., \& Maccarone, E. (1999). Possible alternative utilization of Cynara spp. I. Biomass, grain yield and chemical composition of grain. Industrial Crops and Products, 10(3), 219-228. https://doi.org/ 10.1016/S0926-6690(99)00026-6.

Francaviglia, R., Bruno, A., Falcucci, M., Farina, R., Renzi, G., Russo, D. E., ... Neri, U. (2016). Yields and quality of Cynara cardunculus L. wild and cultivated cardoon genotypes. A case study from a marginal land in Central Italy. European Journal of Agronomy, 72, 10-19. https://doi.org/10.1016/j.eja.2015.09.014.

Georgieva, E., Karamalakova, Y., Nikolova, G., Grigorov, B., Pavlov, D., Gadjeva, V., \& Zheleva, A. (2014). Radical scavenging capacity of seeds and leaves ethanol extracts of Cynara scolymus L. - A comparative study. Biotechnology and Biotechnological Equipment, 26(April 2017), 151-155. https://doi.org/10.5504/50YRTIMB.2011. 0028.

Guil, J. L., Torija, M. E., Giménez, J. J., Rodríguez-García, I., \& Himénez, A. (1996). Oxalic acid and calcium determination in wild edible plants. Journal of Agricultural and Food Chemistry, 44(7), 1821-1823. https://doi.org/10.1021/jf950472a.

Guimarães, R., Barros, L., Dueñas, M., Calhelha, R. C., Carvalho, A. M., Santos-Buelga, C., ... Ferreira, I. C. F. R. (2013). Nutrients, phytochemicals and bioactivity of wild Roman chamomile: A comparison between the herb and its preparations. Food Chemistry, 136(2), 718-725. https://doi.org/10.1016/j.foodchem.2012.08.025.

Khaldi, S., Chaouachi, F., Ksouri, R., \& Gazzah, M. El. (2013). Polyphenolic composition in different organs of Tunisia populations of Cynara cardunculus L. and their antioxidant activity. Journal of Food and Nutrition Research, 1(1), 1-6. https://doi.org/10. 12691/JFNR-1-1-1.

Kollia, E., Markaki, P., Zoumpoulakis, P., \& Proestos, C. (2016). Antioxidant activity of Cynara scolymus L. and Cynara cardunculus L. extracts obtained by different extraction techniques. Natural Product Research, 31(10), 1163-1167. https://doi.org/10.1080/ 14786419.2016.1219864.

Llorente, B. E., Obregón, W. D., Avilés, F. X., Caffini, N. O., \& Vairo-Cavalli, S. (2014). Use of artichoke (Cynara scolymus) flower extract as a substitute for bovine rennet in the manufacture of Gouda-type cheese: Characterization of aspartic proteases. Food Chemistry, 159, 55-63. https://doi.org/10.1016/j.foodchem.2014.03.007.

Lombardo, S., Pandino, G., Mauromicale, G., Knödler, M., Carle, R., \& Schieber, A. (2010). Influence of genotype, harvest time and plant part on polyphenolic composition of globe artichoke [Cynara cardunculus L. var. scolymus (L.) Fiori]. Food Chemistry, 119(3), 1175-1181. https://doi.org/10.1016/j.foodchem.2009.08.033.

Maccarone, E., Fallico, B., Fanella, F., Mauromicale, G., \& Raccuia, S. A. (1999). Possible alternative utilization of Cynara spp. II. Chemical characterization of their grain oil. Industrial Crops and Products, 10, 229-237. https://doi.org/10.1016/S0926-6690(99) 00027-8.

Mancini, M., Lanza Volpe, M., Gatti, B., Malik, Y., Moreno, A. C., Leskovar, D., \& Cravero, V. (2019). Characterization of cardoon accessions as feedstock for biodiesel production. Fuel, 235, 1287-1293. https://doi.org/10.1016/j.fuel.2018.08.123.
Moglia, A., Lanter, S., Comino, C., Acquadro, A., De Vos, R., \& Beekwilder, J. (2008). Stress-induced biosynthesis of dicaffeoylquinic acids in globe artichoke. Journal of Agricultural and Food Chemistry, 56(18), 8641-8649. https://doi.org/10.1021/ jf801653w.

Moreau, A. G., \& Savage, G. P. (2009). Oxalate content of purslane leaves and the effect of combining them with yoghurt or coconut products. Journal of Food Composition and Analysis, 22(4), 303-306. https://doi.org/10.1016/j.jfca.2009.01.013.

Murad, L. D., da Soares, N. da C. P., Brand, C., Monteiro, M. C., \& Teodoro, A. J. (2015) Effects of caffeic and 5-caffeoylquinic acids on cell viability and cellular uptake in human colon adenocarcinoma cells. Nutrition and Cancer, 67(3), 532-542. https:// doi.org/10.1080/01635581.2015.1004736.

Nouraei, S., Rahimmalek, M., Saeidi, G., \& Bahreininejad, B. (2016). Variation in seed oil content and fatty acid composition of globe artichoke under different irrigation regimes. Journal of the American Oil Chemists' Society, 93(7), 953-962. https://doi.org/ 10.1007/s11746-016-2852-3.

Pereira, C., Barros, L., Carvalho, A. M., \& Ferreira, I. C. F. R. (2013). Use of UFLC-PDA for the analysis of organic acids in thirty-five species of food and medicinal plants. Food Analytical Methods, 6(5), 1337-1344. https://doi.org/10.1007/s12161-012-9548-6.

Petropoulos, S. A., Fernandes, Â., Barros, L., Ciric, A., Sokovic, M., \& Ferreira, I. C. F. R. (2017). The chemical composition, nutritional value and antimicrobial properties of Abelmoschus esculentus seeds. Food \& Function, 8, 4733-4743. https://doi.org/10. 1039/c7fo01446e.

Petropoulos, S. A., Fernandes, Â., Barros, L., Ferreira, I. C. F. R., \& Ntatsi, G. (2015). Morphological, nutritional and chemical description of "Vatikiotiko", an onion local landrace from Greece. Food Chemistry, 182, 156-163. https://doi.org/10.1016/j foodchem.2015.03.002.

Petropoulos, S. A., Fernandes, Â., Calhelha, R. C., Danalatos, N., Barros, L., \& Ferreira, I. C. F. R. (2018). How extraction method affects yield, fatty acids composition and bioactive properties of cardoon seed oil? Industrial Crops and Products, 124(June), 459-465. https://doi.org/10.1016/j.indcrop.2018.08.027.

Petropoulos, S. A., Pereira, C., Ntatsi, G., Danalatos, N., Barros, L., \& Ferreira, I. C. F. R. (2017). Nutritional value and chemical composition of Greek artichoke genotypes. Food Chemistry. https://doi.org/10.1016/j.foodchem.2017.01.159.

Petropoulos, S. A., Pereira, C., Tzortzakis, N., Barros, L., \& Ferreira, I. C. F. R. (2018), Nutritional value and bioactive compounds characterization of plant parts from Cynara cardunculus L. (Asteraceae) cultivated in central Greece. Frontiers in Plant Science, 9, 1-12. https://doi.org/10.3389/fpls.2018.00459.

Petropoulos, S., Karkanis, A., Fernandes, Â., Barros, L., Ferreira, I. C. F. R., Ntatsi, G., ... Khah, E. (2015). Chemical composition and yield of six genotypes of common purslane (Portulaca oleracea L.): An alternative source of omega-3 fatty acids. Plant Foods for Human Nutrition, 70(4), 420-426. https://doi.org/10.1007/s11130-015-0511-8.

Raccuia, S. A., \& Melilli, M. G. (2007). Biomass and grain oil yields in Cynara cardunculus L. genotypes grown in a Mediterranean environment. Field Crops Research, 101(2), 187-197. https://doi.org/10.1016/j.fcr.2006.11.006.

Raccuia, S. A., Melilli, M. G., Argento, S., \& Scalisi, C. (2013). Chemical characterization of the achenes in Cynara cardunculus L. var. altilis to recover oil and biocompounds. Retrieved from Acta Horticulturae, 983, 103-108. https://www.scopus.com/inward/ record.uri?eid $=2$-s2.0-84879300410\&partnerID $=40 \& \mathrm{md} 5=$ f4a3b345a0b100d3a600c0d3f02aeb13.

Simopoulos, A. P. (1997). Essential fatty acids in health and chronic disease. Food Reviews International, 13(4), 623-631. https://doi.org/10.1081/FRI-120028831.

Simopoulos, A. P. (2008). The importance of the omega-6/omega-3 fatty acid ratio in cardiovascular disease and other chronic diseases. Experimental Biology and Medicine, 233(6), 674-688.

Soković, M., Glamočlija, J., Marin, P. D., Brkić, D., \& van Griensven, L. J. L. D. (2010). Antibacterial effects of the essential oils of commonly consumed medicinal herbs using an in vitro model. Molecules, 15(11), 7532-7546.

Soković, M., \& Van Griensven, L. J. L. D. (2006). Antimicrobial activity of essential oils and their components against the three major pathogens of the cultivated button mushroom, Agaricus bisporus. European Journal of Plant Pathology, 116(3), 211-224. https://doi.org/10.1007/s10658-006-9053-0.

Zonta, F., \& Stancher, B. (1983). High-performance liquid chromatography of tocopherols in oil and fats. Rivista Italiana Delle Sostanze Grasse, 60, 195-199. 